Chirurgia (2018) 113: 576-581

No. 4, July - August

Copyright@ Celsius

http://dx.doi.org/10.21614/chirurgia.113.4.576

\title{
Jejunal Diverticulitis Mimicking Small Bowel Perforation: Case Report and Review of the Literature
}

\author{
Athanasios Syllaios', Antonios Koutras ${ }^{2}$, Prokopis A. Zotos ${ }^{3}$, Evangelia Triantafyllou ${ }^{4}$, Nikolaos Bourganos ${ }^{1}$, \\ Sofia Koura ${ }^{2}$, Aristotelis Liakos ${ }^{1}$
}

'Department of Surgery, General Hospital of Lamia, Greece

'Department of Obstetrics and Gynecology, General Hospital of Athens 'Laiko', Athens, Greece

${ }^{3}$ Department of Surgery, General Military Hospital, Larisa, Greece

${ }^{4}$ Department of Surgery, Mpodosakeio Hospital, Ptolemaida, Greece

Corresponding author:

Athanasios Syllaios, MD

Kountourioti 5, Lamia 35100, Greece

E-mail: nh_reas@hotmail.com

\section{Rezumat}

Diverticulita jejunală care imită perforarea intestinului subtire: prezentare de caz și analiza literaturii

Diverticulita jejunală este o afecțiune rară, cu prevalență ridicată la pacientiii cu vârsta între 60-70 de ani. Diverticulul jejunal este considerat ca o descoperire accidentală, dar care poate avea complicații ca de exemplu diverticulita, perforație, abces, peritonită generalizată, fistulă, obstrucție şi sângerare. Stabilirea unui diagnostic rămâne în continuare o provocare. Medicii trebuie să fie conştienți de existența acestora şi suspiciunea clinică trebuie menționată, mai ales în condițiile unei dureri abdominale acute, caz în care diverticulita jejunal trebuie inclusă în diagnosticul diferențial. O cantitate redusă de aer adiacent intestinului subțire poate crea confuzie fiind diagnosticat greşit ca perforație a intestinului subțire, când de fapt poate fi rezultatul inflamației fără macroperforație sau complicații. Acest lucru poate schimba strategia terapeutică spre una mai puțin agresivă, spre tratament conservator. Prezentăm cazul unui pacient care se prezintă la serviciul de urgență cu durere abdominală acută, semne de peritonită; o cantitate mică de aer extraluminal şi diverticulita jejunal fără perforație au fost diagnosticate în cadrul laparotomiei şi după analiza literaturii de specialitate.

Cuvinte cheie: diverticulită jejunală, perforație, durere abdominală acută, diagnostic diferential, intestin subtire 


\begin{abstract}
Jejunal diverticulitis is a rare entity with a higher prevalence among patients between 60 and 70 years. Jejunal diverticula are most often considered an incidental finding, but, they can have complications such as diverticulitis, perforation, abscess, generalized peritonitis, fistula, obstruction and bleeding.Setting the diagnosis still remains challenging. Physicians should be aware of their existence and the clinical suspicion should be raised, especially in the setting of acute abdominal pain where jejunal diverticulitis should be included in the differential diagnosis. A small amount of free air adjacent to the small bowel can be confusing and easily misdiagnosed as small bowel perforation, but, it can actually be found as a result of the inflammation itself without macroperforation or complications.This fact can change the therapeutic strategy to less aggressive, conservative treatments. We present a case of a patient coming to the emergency department with acute abdominal pain, signs of peritonitis, a small amount of extraluminal air, and jejunal diverticulitis without perforation was diagnosed on laparotomy, and a review of the current literature.
\end{abstract}

Key words: jejunal diverticulitis, diverticula, perforation, jejunum, acute abdominal pain, differential diagnosis, small bowel

\section{Introduction}

Unlike colonic diverticula, small bowel diverticula are a rare entity. They appear after the fifth decade of age, mainly between 60 and 70 years with a prevalence of 1 to $4.6 \%$ (1). Jejunoilel diverticula have a higher prevelance in males, while duodenal diverticula occur equally in males and females (2). They are most often considered an incidental finding and seem to be more prevalent in the duodenum (approximately five times more common than jejunoileal diverticula). There is little data about diverticular disease in the small bowel, despite the fact that diagnostic capabilities improved in recent years.It can be quite difficult to diagnose and identify this disorder. Diagnosis is most frequently made incidentally by radiographic examination or upon laparotomy due to complications (3). Jejunal diverticula can have dramatic complications such as jejunal diverticulitis $(2-6 \%)$, perforation $(2.1-7 \%$ of diverticulitis), abscess, generalized peritonitis, fistula, mechanical intestinal obstruction and diverticular bleeding(1). Diverticulitis, generally, is best defined as the microperforation or macroperforation of diverticula causing localized inflammation that may progress to more generalized manifestations (4). Our main objective is to present this rare entity as potential cause in the differential diagnosis of acute abdomen, particularly among patients aged 60 or older, and to raise clinical suspicion to physicians, who should be alerted that a small amount of extraluminal air $(\leq 2 \mathrm{~cm}$ in diameter) could be attributed to jejunal diverticulitis and not to free perforation of the small intestine.

\section{Case Report}

A 75-year-old man was referred to the surgical emergency department because of severe acute abdominal pain, fever and abdominal distention. The patient complained of abdominal pain during defecation for about two days, as well as a change in bowel habits for about a month. His medical history was unremarkable and he had never undergone an endoscopy or a surgery before. The physical examination revealed abdominal tenderness and rigidity. The abdominal pain was diffuse and severe. His vital signs were stable, but his temperature reached $38,5^{\circ} \mathrm{C}$. His $\mathrm{WBC}$ count was $18,0 \times 10^{9} / \mathrm{L}$ and his CRP was $100 \mathrm{mg} / \mathrm{L}$. All other laboratory data were within normal limits.

The plain abdominal and chest X-ray were 
normal. Pneumoperitoneum was not visible. The abdominal computed tomography (CT) scan revealed the presence of a small amount of extraluminal air ( $2 \mathrm{~cm}$ in diameter) adjacent to the jejunum, as well as a large, $3.5 \times 4 \mathrm{~cm}^{2}$, abscess adherent to the jejunum (Fig. 1).

At exploratory laparotomy, 6 large jejunal diverticula were found without obvious perforation, free fluid or abscess (Fig. 2).According to CT findings, perforation was expected to be found. However, free perforation within the peritoneal cavity was not seen. A partial enterectomy of $45 \mathrm{~cm}$ jejunum including the diverticulawas performed. The remainder of the small bowel appeared normal. The bowel continuity was restored with primary side-toside anastomosis. The postoperative recovery was uneventful and the patient was discharged on postoperative day 6 .

Pathological assessment of the specimen showed jejunal diverticulosis with extensive acute necrotizing inflammation in 4 of the diverticula and foreign-body giant cell reaction. They were classified as false diverticula, as they consisted of the uncus of the mucosa and the submucosa. None of the diverticula was ruptured.

\section{Discussion}

A diverticulum is a bulging sack in any portion of the gastrointestinal tract. Jejunal diverticulosis was first described in 1794 by Sommering. Unlike the true congenital Meckel's diverticulum, acquired jejunal diverticula are characterized by herniation of mucosa and submucosa through the muscular layer of the bowel wall (false diverticula) on the mesenteric border of the bowel, at the blood vessel penetration sites (5). Although their prevalence is about $2 \%$ and is associated with older age, only about $3 \%$ of them are clinically important and can be appeared with symptoms such as inflammation (jejunal diverticu-litis). Coexistent diverticula can be found in the colon in $50 \%$, in the duodenum in $30 \%$, in the esophagus and stomach in $2 \%$ of patients (6).

The etiology is unknown. The main hypo-

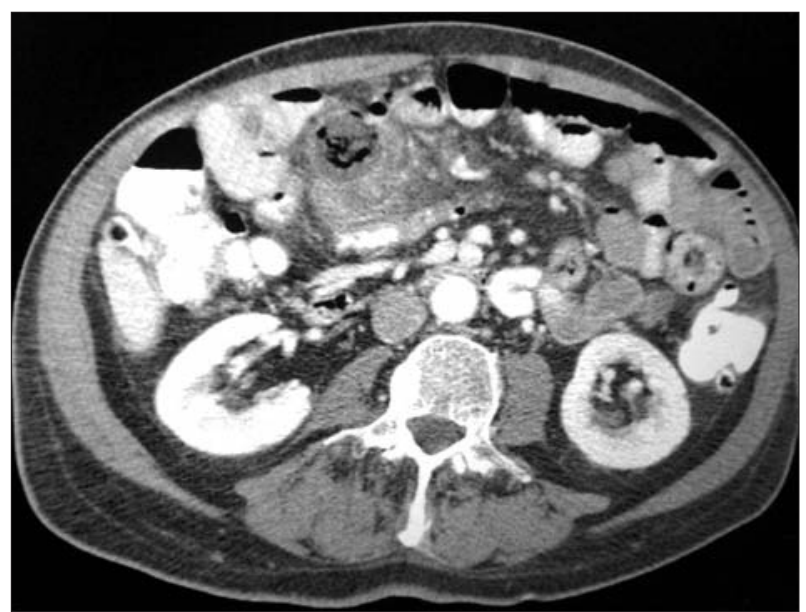

Figure 1. Abdominal CT showing a small amount of extraluminal air adjacent to the jejunum

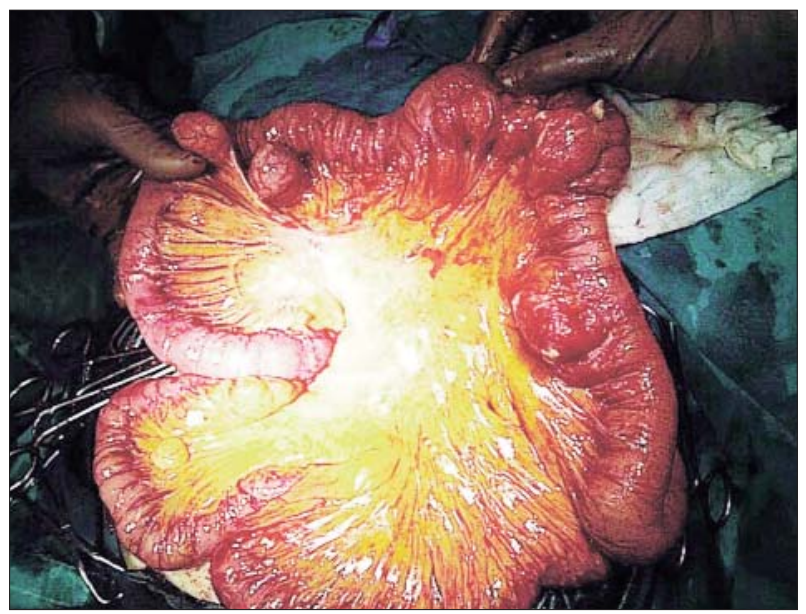

Figure 2. Jejunal diverticulitis on laparotomy

thesis to the etiology of jejunal diverticula focuses on abnormalities in the smooth muscle or myenteric plexus that can lead to distorted smooth muscle contractions (abnormalities in intestinal peristalsis, intestinal dyskinesis) of the affected small bowel generating increased intraluminal pressure (7). Jejunal diverticulitis can then occur either by the stasis of the intestinal contents in the diverticulum or by mucosal edema obstructing the neck of the diverticulum favouringintradiverticular microbial growth (1). The larger size of the jejunal diverticulum, the relatively sterile content and the better intraluminal flow are factors that prevent those diverticula from diverticulitis (8).

The clinical presentation of jejunal diverticula 
can be variable and the diagnosis may be delayed until a complication has emerged. The disorder is clinically silent or it can mimic irritable bowel syndrome symptoms: chronic abdominal pain, bloating sensation after food intake, abdominal cramping of unexplained cause, diarrhea and other disorders of intestinal transit. Physical findings, also, include a sensation of vague or localized pain, rectal bleeding and abdominal fullness $(1,2,3)$. No sign or symptom is pathognomonic of small intestine diverticular disease; in the absence of complications, medical history and physical examination, findings are often negative and nearly all patients are diagnosed incidentally. Jejunal diverticulitis can easily be confused with acute appendicitis, acute cholecystitis, colonic diverticulitis, perforated ulcer, as the symptoms are non-specific and is manifested with acute abdominal pain (1). Jejunal diverticula complications are more often in patients with multiple diverticula and include diverticulitis ( $2-6 \%$ of patients), perforation (2.1$7 \%$ of diverticulitis), obstruction $(2.3-4.6 \%$ of patients) and bleeding (2-8.1\% of patients). Perforation may present as a localised perforation with or without generalized peritonitis. The localised perforation leads to the formation of a mesenteric abscess (9), an intra-peritoneal abscess, fistulas and liver abscess (10). Factors for perforation have been shown to be related to a necrotizing inflammatory reaction in $82 \%$ of cases, followed by blunt trauma in $12 \%$ of cases and foreign body impaction in $6 \%$ of cases (11). Bleeding from jejunal diverticula presents as acute or chronic lower gastrointestinal bleeding with iron deficiency anaemia noted and has a similar etiology to that seen in the large bowel diverticula in that the diverticulum erodes through a perforating artery. Haemetemesis has also been reported (12). Hemorrhage in jejunum cannot be detected with endoscopic techniques. Small bowel contrast studies, computed tomography scans, mesenteric angiogram and technetium red cell-tagged scan establish the diagnosis. Mechanical intestinal obstruction is the least common complication of jejunal diverticulosis and may be related to extrinsic compression from a nearby loop of jejunum containing a large diverticulum or from intus- susception (9). Dyskinesia may be a nonmechanical reason for intestinal obstruction (13). Some cases of obstruction caused by enterolith impaction complicating jejunal diverticulitis have been reported (14).

Setting the diagnosis with imaging alone is quite difficult and challenging. Almost half of symptomatic small bowel diverticula were not detected with preoperative imaging according to Kouraklis et al (15). Abdominal ultrasound, computed tomography (CT), magnetic resonance enterography/enteroclysis, barium imaging, endoscopy (capsule endoscopy and double-balloon enteroscopy) have been tried to set the diagnosis to jejunal diverticulosis, to jejunal diverticulitis and its' complications. Their role and their utility in emergency settings remains controversial and limited (1). Currently, multi-detector row computed tomography (MDCT) is considered the gold-standard for the detection of jejunal diverticulitis and the complicatons (3). CT findings include: focal and assymetric thickening of the intestinal wall, abscess adjacent to the jejunal loop, edema of the surrounding mesenteric fat, inflammatory mass and edema in the surrounding peridiverticular fat, and "arrowhead-shaped collection of contrast" sign (1). Pneumoperitoneum is usually found after perforation. However, rarely it can be found without obvious perforation or signs of peritonitis. The physiopathological mechanisms are thought to be a rapidly closed leaking diverticulum (microperforation) and the transmural passage of air through a thin-walled diverticulum (semipermeable membrane)(16). In our patient the small amount of extraluminal air along with his clinical condition and the signs of peritonitis lead to the diagnosis of small bowel perforation and to surgical intervention, although on laparotomy no obvious perforation of a diverticulum existed. This should be always kept in mind, that jejunal diverticulitis is in fact microperforation and a small amount of free air could be explained due to the inflammation itself. It can easily trick physicians to misdiagnose jejunal diverticulitis as small bowel perforation, as diverticulitis with pneumoperitoneum and no perforation is extremely rare in the small intestine. Laparoscopy can be a very useful 
diagnostic tool in evaluating patients with a complicated course. The diagnosis is more accurate and an unnecessary laparotomy could be avoided if not indicated (17). Expertise and experience is necessary for a more accurate diagnosis with diagnostic laparoscopy.

Uncomplicated jejunal diverticulitis can be managed with systemic antibiotic therapy and fasting, that should be considered as the first line therapy for stable patients without signs of peritonitis (18). This approach has the advantages of preserving bowel length and has no risk for later complications such as adhesion, obstructive ileus and surgical wound infection. However, there is a high risk of recurrence and complications because of the inflammation. In addition to this, jejunal diverticula are 18 times more likely to perforate so aggressive surgical therapy must be considered even in uncomplicated jejunal diverticulitis (19).Peri-diverticular abscesses when they are smaller than $5 \mathrm{~cm}$ can be treated with CT-guided drainage and antibiotic therapy. When the abscesses or the peri-diverticular collection are bigger than $5 \mathrm{~cm}$ surgery is recommended (1). Laparotomy and bowel resection is mandatory when percutaneous drainage can't be performed. Liver abscesses because of hematogenous spread from a perforated jejunal diverticulitis are a rare complication. CT-guided percutaneous drainage is the best therapeutic choice (9).Currently, in patients with peritonitis and perforation bowel resection should be performed. In our patient the signs of peritonitis and the CT findings lead to surgical management and the resection of the small bowel's segment containing the diverticula. According to patient's general condition and the intestinal wall's condition primary bowel anastomosis is recommended. Management for perforated jejunal diverticula has no clear guidelines and it is based on isolated reports. Conservative management with intravenous antibiotics and drainage has been proposed (20). A few case reports have documented successful management with observation and laparoscopic lavage in cases of micro-perforation (21). Jejunostomy is an alternative approach for high risk patients (18). Simple closure of the perforated diverticulum or diverticulectomy are associated with high mortality rate (22). On the other hand, in the case of a perforated diverticulum next to duodeno-jejunal flexure, simple closure or diverticulectomy is appropriate because at this anatomic region anastomotic complications are difficult to be managed. If there is extensive jejunal diverticulosis, it is preferable to resect only the intestinal loop with the perforation. Short bowel syndrome can be avoided with this approach (1). On the other hand, resection is obligatory in case of large diverticula with dilated intestinal loops to prevent the high rate of complications. As far as acute intestinal obstruction is concerned, surgery and resection of the stenotic portion of the bowel must be performed. Conservative management is usually useless. When it comes to diverticular bleeding, laparotomy, hemorrhage control and intestinal resection must be performed (14). Asymptomatic diverticula discovered during laparotomy or diagnostic imaging for other conditions do not require any intervention. Finally, laparoscopy should be considered as an option in cases where imaging studies are not diagnostic.

Because of the high incidence of coexistent colonic diverticula all patients with JD must have routine colonoscopy (9). The mortality rate of jejunal diverticulitis ranges from $0-5 \%$ but in case of perforation mortality can reach $40 \%$ (23). Poor prognostic factors are perforation, delayed diagnosis, the time between perforation and surgery, advanced age and associated comorbidities (7).

\section{Conclusion}

In conclusion, jejunal diverticulitis is a rare entity and, despite the fact, that diagnostic capabilities improved in recent years, setting the diagnosis of jejunal diverticulitis still remains challenging, with the $\mathrm{CT}$ being the most valuable tool in the evaluation of jejunal diverticulitis and the complications. Hence, we suggest that this particular condition should be considered in the differential diagnosis of acute abdominal pain, especially for patients with a high risk for diverticular disease. A small amount of free air adjacent to the small bowel 
could be attributed to jejunal diverticulitis without macroperforation or complications and this fact can change the therapeutic strategy to less aggressive, conservative treatments. Diagnostic laparoscopy is very useful for a more accurate diagnosis in those controversial situations.

\section{Conflicts of Interest and Funding}

None declared.

\section{Author's Contributions}

All authors contributed the same.

\section{Rerences}

1. Harbi H, Kardoun N, Fendri S, Dammak N, Toumi N, Guirat A, et al. Jejunal diverticulitis. Review and treatment algorithm. Presse Med. 2017;46(12 Pt 1):1139-1143.

2. Ferreira-Aparicio FE, Gutiérrez- Vega R, Gálvez-Molina Y, OntiverosNevares P, Athie-Gútierrez C, Montalvo-Javé E. Diverticular Disease of The Small Bowel, Case Rep Gastroenterol. 2012;6(3):668-676.

3. Macari M, Faust M, Liang H, Pachter HL. CT of jejunal diverticulitis: imaging findings, differential diagnosis, and clinical management. Clin Radiol 2007;62(1):73-7.

4. Köhler L, Sauerland S, Neugebauer E. Diagnosis and treatment of diverticular disease: results of a consensus development conference. The Scientific Committee of the European Association for Endoscopic Surgery. SurgEndosc. 1999;13(4):430-6.

5. Williams RA, Davidson DD, Serota Al, Wilson SE. Surgical problems of diverticula of the small intestine. SurgGynecol Obstet. 1981;152:621-626

6. Chow DC, Babaian M, Taubin HL. Jejunoileal diverticula. Gastroenterologist. 1997:5:78-84.

7. Krishnamurthy S, Kelly MM, Rohrmann CA, Schuffler MD. Jejunal diverticulosis. A heterogenous disorder caused by a variety of abnor- malities of smooth muscle or myenteric plexus. Gastroenterology. 1983:85:538-547.

8. Benya EC, Ghahremani GG, Brosnan JJ. Diverticulitis of the jejunum: clinical and radiological features. GastrointestRadiol 1991;16(1): 24-8.

9. Longo WE, Vernava AM 3rd. Clinical implications of jejunoileal diverticular disease. Dis Colon Rectum. 1992;35:381-388

10. Horesh N, Klang E, Gravetz A, Nevo Y, Amiel I, Amitai MM, et al. Jejunal diverticulitis. J Laparoendosc Adv Surg Tech A 2016;26(8): $596-9$

11. Herrington $\mathrm{JL} J \mathrm{~J}$. Perforation of acuired diverticula of the jejunum and ileum. Analysis of reported cases. Surgery. 1962;51:426-433

12. Altemieir WA, Bryant LR. The surgical significance of jejunal diverticulosis. Arch Surg. 1963;86:732-745.

13. Krishnamurthy S, Kelly MM, Rohrmann CA, Schuffler MD. Jejunal diverticulosis. A heterogenous disorder caused by a variety of abnormalities of smooth muscle or myenteric plexus. Gastroenterology. 1983:85:538-547.

14. Harris LM, Volpe CM, Doerr RJ. Small bowel obstruction secondary to enterolith impaction complicating jejunal diverticulitis. Am J Gastroenterol. 1997Sep;92(9):1538-40.

15. Kouraklis G, Glinavou A, Mantas D, KouskosvE, Karatzas G. Clinical implications of small bowel diverticula. Isr Med Assoc J 2002;4:431-3

16. Kwak JY, Park EH, Park CS, Kim JH, Han MS, Kwak JH. Uncomplicated jejunal diverticulosis with pneumoperitoneum. Ann Surg Treat Res 2016;90(6):346-9

17. Koger KE, Shatney CH, Dirbas FM, McClenathan JH. Perforated jejunal diverticula. Am Surg. 1996;62:26-29.

18. Kassahun WT, Fangmann J, Harms $J$, Bartels $M$, Hauss $J$. Complicated small-bowel diverticulosis: a case report and review of the literature. World J Gastroenterol 2007:13(15):2240-2.

19. Chendrasekhar A, Timberlake GA. Perforated jejunal diverticula: an analysis of reported cases. Am Surg. 1995 Nov;61(11):984-8.

20. Levack MM, Madariaga ML, Kaafarani HM. Non-operative successful management of a perforated small bowel diverticulum. World J. Gastroenterol. 2014;20:18477-18479.

21. Myers E., Hurley M., O'Sullivan G.C. Laparoscopic peritoneal lavage for generalized peritonitis due to perforated diverticulitis. $\mathrm{Br}$. J. Surg. 2008:95:97-101.

22. Englund $R$, Jensen $M$. Acquired diverticulosis of the small intestine: case reports and literature review. Aust N Z J Surg. 1986;56(1):51-4.

23. Kassir R, Boueil-Bourlier A, Baccot S, Abboud K, Dubois J, Petcu $\mathrm{CA}$, et al. Jejuno-ileal diverticulitis: etiopathogenicity, diagnosis and management. Int J Surg Case Rep 2015;10:151-3. 